ISSN: 2548 - 1843

\title{
HUBUNGAN FAKTOR-FAKTOR YANG MEMENGARUHI KEPATUHAN MINUM OBAT DENGAN KEPATUHAN PASIEN SKIZOFRENIA YANG MENGALAMI HALUSINASI DI RS HUSADA
}

\author{
Tri Setyaningsih*) \\ Dian Fitria*) \\ Supriyanah**) \\ *)Dosen Akademi Keperawatan RS Husada, Jakarta, 10730, Indonesia \\ **)RS Husada, Jakarta, 10730, Indonesia; Program Studi Ilmu Keperawatan \\ Stikes Binawan
}

\begin{abstract}
Abstrak
Skizofrenia adalah gangguan mental kronis yang menyebabkan penderitanya mengalami delusi, halusinasi, pikiran kacau, dan perubahan perilaku. Penelitian ini dilakukan untuk mengetahui hubungan gambaran faktor-faktor yang memengaruhi kepatuhan minum obat terhadap kepatuhan pasien skizofrenia yang mengalami halusinasi di RS Husada. Penelitian ini menggunakan metode deskriptif korelatif. Populasi dalam penelitian ini adalah semua pasien skizofrenia yang dirawat di Ruang Nusa Indah RS Husada. Sampel pada penelitian ini sebanyak 24 orang dengan tehnik pengambilan sampel accidental sampling. Hasil penelitian menunjukkan ada hubungan yang bermakna antara dukungan keluarga terhadap kepatuhan minum obat ( $p$ value 0,005 ), perilaku terhadap kepatuhan minum obat ( $p$ value 0,006$)$, tingkat ekonomi terhadap kepatuhan minum obat ( $p$ value 0,005 ), tingkat pendidikan terhadap kepatuhan minum obat ( $p$ value $0,031)$, pengetahuan terhadap kepatuhan minum obat ( $p$ value 0,035$)$ dan dukungan sosial terhadap kepatuhan minum obat ( $p$ value 0,037$)$.
\end{abstract}

Kata kunci: skizofrenia, kepatuhan minum obat, skizofrenia, halusinasi

\begin{abstract}
Schizophrenia is a chronic mental disorder that causes the sufferer to experience delusions, hallucinations, chaotic thoughts, and behavioral changes. This study was conducted to determine the relationship of the description of the factors that influence the adherence of medication to the compliance of schizophrenic patients who experienced hallucinations in Husada Hospital. This research uses correlative descriptive method. The population in this study were all schizophrenic patients who were treated in Nusa Indah Room RS Husada. Sample in this research counted 24 people with accidental sampling sampling technique. The results of the study showed that there was a significant correlation between family support for medication adherence ( $p$ value 0,005), behavior toward drug adherence ( $p$ value 0,006), economic level of drug adherence compliance ( $p$ value 0,005), education level to medication adherence $p$ value 0.031), knowledge of medication adherence ( $p$ value 0.035) and social support for medication adherence ( $p$ value 0.037).
\end{abstract}

Keywords: schizophrenia, medication adherence, schizophrenia, hallucinations 


\section{PENDAHULUAN}

Skizofrenia adalah penyakit otak yang menyebabkan seseorang menjadi disfungsional secara fisiologis untuk dirinya sendiri maupun interaksi secara sosial. Kira - kira 15 dari jumlah seluruh penduduk di dunia mengidap penyakit ini, bahkan lebih dari 2 juta orang Amerika mengidap penyakit ini (National Institute Of Mental Health, 2002). Penyakit ini sering muncul pada awal usia 20 tahun sehingga akan mengurangi produktivitas kehidupan secara mendadak (Sadock \& Sadock, 2007). Orang yang mengidap skizofrenia tidak akan mampu berkomunikasi secara normal dengan orang lain, salah satunya adalah karena menganggap bahwa orang lain ingin mencelakakannya (Sadock \& Sadock, 2010).

Pasien - pasien ini sangat kesulitan berkomunikasi dan berada didalam lingkaran banyak orang. Selain itu mereka pun mengalami halusinasi dan ilusi sehingga seakan melihat hal yang tak nyata (Amlia \& Anwar, 2013). Salah satu teori yang menyebabkan gejala ini adalah kelainan dari regulasi dopamin, sehingga pengobatan yang bersifat antagonis dopamine akan menurunkan gejalan pasien (Sadock \& Sadock,
2010). Pengobatan ini berfokus untuk mengurangi gejala psikosis dengan cepat pada fase akut dan memperpanjang periode relaps serta mencegah pengulangan gejala yang lebih buruk. Selain itu pada pengobatan yang teratur pasien dapat kembali kedalam lingkaran sosialnya dalam waktu yang lebih cepat. Pasien yang menjalani pengobatan secara rutin selama satu tahun memiliki resiko lebih kecil untuk mengalami relaps (Zygmunt, Offson, Boyer, \& Mechanic, 2002). Banyak penelitian dibuktikan bahwa $50 \%$ pasien skizofrenia yang masuk kerumah sakit jiwa kemudian dilakukan rawat jalan malah mengalami masalah ketidakpatuhan (Poor Andherenca).

Hal ini dapat mengakibatkan masalah baru pada pasien skizofrenia yaitu pasien lebih muda jatuh kedalam kondisi relaps dan kekambuhan fase psikosis yang lebih buruk, keluar masuk rumah sakit berulang kali, serta meningkatkan beban sosial dan ekonomi bagi keluarga pasien dan Negara. Hal ini diakibatkan pasien yang tidak teratur dalam minum obat akan memiliki resiko kekambuhan sebesar 92\% (Ferton, 1997). 
Pengobatan tidak akan menyembuhkan pasien sembuh $100 \%$ tetapi dengan pengobatan maka waktu remisi pasien setahun lebih lama dan gejala psikosis tidak akan terlalu parah. Hal ini tentunya akan memperingati beban hidup pasien (Zygmunt, 2002). Banyak penelitian yang membuktikan bahwa intervensi terhadap masalah kepatuhan ini sangat diperlukan untuk meningkatkan kualitas hidup pasien. Hal ini bisa dilakukan melalui terapi kognitif - prilaku, komunikasi keluarga, dan terapi komunikasi untuk meningkatkan kepatuhan minum obat melalui peningkatan pemahaman pasien. Sehingga perlu diketahui faktor - faktor terkait ketidakpatuhan (Zygmunt et al 2002).

Beberapa faktor yang mempengaruhi ketidakpatuhan antara lain faktor dukungan keluarga, prilaku, sikap dan pengobatan, tingkat ekonomi, pendidikan, akomodasi, lingkungan sosial, dekat ke pelayanan kesehatan, pengetahuan dan dukungan sosial.

Rumah Sakit Husada adalah rumah sakit umum pusat wilayah utara, merupakan Rumah Sakit rujukan dari rumah sakit, puskesmas, dan klinik - klinik yang ada di sekitarannya. Sebagai Rumah Sakit tipe B rumah sakit Husada menyediakan berbagai macam pelayanan kesehatan, baik rawat inap maupun rawat jalan. Salah satu sarana yang tersedia di rawat inap adalah ruangan psikiatri yang bernama Pavilium Nusa Indah, tempat yang akan dilakukan penelitian. Dari survey awal yang peneliti lakukan di Rumah Sakit Husada, ingin mengetahui faktor - faktor apa saja yang mempengaruhui kepatuhan minum obat pada pasien halusinasi. Di Rumah Sakit Husada Ruang Psikiatri dengan jumlah tempat tidur 24, rata - rata BOR perhari pada tahun 2014 sebanyak 55 - 58\%, 25 - 30\% diantaranya mengalami gangguan skizofrenia dan mengalami gejala halusinasi, serta mengalami kekambuhan akibat ketidakpatuhan minum obat.

Dengan menemukan alasan ketidakpatuhan minum obat pada pasien skizofrenia yang mengalami halusinasi dapat menjadi masukan untuk perbaikan sistem pengobatan baik untuk pasien, keluarga dan sistem kesehatan pada umumnya.

\section{METODE}

Desain penelitian ini menggunakan desain deskriptif korelatif. Desain deskriptif korelatif adalah menguji 
hubungan antara variabel dalam sebuah kelompok dengan tujuan untuk mendeskripsikan variabel-variabel (Burn \& Grove, 2009), dengan total sampel 24 orang. Tehnik pengambilan sampel menggunakan metode accidental sampling dengan kriteria inklusi: pasien bersedia menjadi responden, pasien skizofrenia mengalami halusinasi pada tahap comforting, pasien dirawat di ruang Nusa Indah RS Husada Jakarta, kooperatif saat dilakukan penelitian. Lokasi penelitian pada penelitian ini yaitu di Ruang Nusa Indah Rumah Sakit Husada. Penelitian ini dilakukan pada bulan Februari sampai Maret 2015.

\section{HASIL}

Analisa univariat ini terdiri dari data demografi (jenis kelamin, status perkawinan, pekerjaan, penghasilan keluarga), variabel independen (dukungan keluarga, perilaku, tingkat ekonomi, pendidikan, pengetahuan, dukungan sosial) dan variabel dependen (kepatuhan minum obat pasien skizofrenia).

Hasil analisis univariat didapatkan bahwa responden yang jenis kelamin laki-laki sebanyak 14 orang $(58,3 \%)$, dan responden yang jenis kelamin, responden yang menikah sebanyak 9 orang (37,5\%), dan responden yang belum menikah sebanyak 15 orang $(62,5 \%)$, responden yang pekerjaan swata sebanyak 3 orang (12,5\%), responden yang pekerjaan wirausaha sebanyak 5 orang $(20,8 \%)$, responden yang pekerjaan lainnya sebanyak 4 orang $(16,7 \%)$, dan responden yang tidak bekerja sebanyak 12 orang (50\%), responden yang penghasilan keluarga Rp. $1,5 \mathrm{jt}-2 \mathrm{jt}$ sebanyak 8 orang $(33,3 \%)$, dan responden yang penghasilan keluarga Rp. 2jt $-2,5 j t$ sebanyak 16 orang $(66,7 \%)$, responden yang dukungan keluarga sedang sebanyak 8 orang $(33,3 \%)$, dan responden yang dukungan keluarga tinggi sebanyak 13 orang (54,2\%), responden yang perilaku buruk sebanyak 9 orang $(37,5 \%)$, dan responden yang perilaku baik sebanyak 15 orang $(62,5 \%)$, responden yang tingkat ekonomi kurang mencukupi sebanyak 2 orang $(8,3 \%)$, responden yang tingkat ekonomi cukup sebanyak 8 orang $(33,3 \%)$, dan responden yang tingkat ekonomi sangat mencukupi sebanyak 14 orang $(58,4 \%)$.

Hasil analisis univariat lain didapatkan bahwa responden yang pendidikan SD 
sebanyak 1 orang $(4,2 \%)$, responden yang pendidikan SMP sebanyak 2 orang $(8,3 \%)$, reponden yang pendidikan SMA sebanyak 13 orang $(54,2 \%)$, dan responden yang pendidikan Perguruan Tinggi sebanyak 8 orang $(33,3 \%)$, responden yang pengetahuan rendah sebanyak 4 orang $(16,7 \%)$, responden yang pengetahuan sedang sebanyak 7 orang $(29,2 \%)$, dan responden yang pengetahuan tinggi sebanyak 13 orang $(54,1 \%)$, responden yang dukungan sosial rendah sebanyak 4 orang $(16,7 \%)$, responden yang dukungan sosial sedang sebanyak 5 orang $(20,8 \%)$, dan responden yang dukungan sosial tinggi sebanyak 15 orang $(62,5 \%)$, responden yang tidak patuh minum obat sebanyak 6 orang (25\%), dan responden yang patuh minum obat sebanyak 18 orang $(75 \%)$.

Tabel 1

Hubungan dukungan keluarga dengan kepatuhan minum obat pasien skizofrenia yang mengalami halusinasi di RS Husada $(n=24)$

\begin{tabular}{|c|c|c|c|c|c|c|c|c|}
\hline \multirow{3}{*}{\multicolumn{2}{|c|}{ Variabel }} & \multicolumn{4}{|c|}{$\begin{array}{c}\text { Kepatuhan Minum } \\
\text { Obat }\end{array}$} & \multirow{2}{*}{\multicolumn{2}{|c|}{ Total }} & \multirow{3}{*}{$\begin{array}{c}\mathrm{P} \\
\text { value }\end{array}$} \\
\hline & & \multicolumn{2}{|c|}{$\begin{array}{l}\text { Tidak } \\
\text { Patuh }\end{array}$} & \multicolumn{2}{|c|}{ Patuh } & & & \\
\hline & & $\mathrm{N}$ & $\%$ & $\mathrm{~N}$ & $\%$ & $\mathrm{~N}$ & $\%$ & \\
\hline \multirow{3}{*}{$\begin{array}{c}\text { Duku } \\
\text { ngan } \\
\text { Kelua } \\
\text { rga }\end{array}$} & Rendah & 3 & 100 & 0 & 0 & 3 & 100 & \multirow{3}{*}{0,005} \\
\hline & Sedang & 2 & 25 & 6 & 75 & 8 & 100 & \\
\hline & Tinggi & 1 & 7,7 & 12 & 92,3 & 13 & 100 & \\
\hline
\end{tabular}

Hasil analisis bivariat didapatkan bahwa bahwa dukungan keluarga rendah dengan tidak patuh minum obat sebanyak 3 orang (100\%), responden dukungan keluarga sedang dengan tidak patuh minum obat sebanyak 2 orang (25\%), responden dukungan keluarga sedang dengan patuh minum obat sebanyak 6 orang (75\%), responden yang dukungan keluarga tinggi dengan tidak patuh minum obat sebanyak 1 orang $(7,7 \%)$, dan responden dukungan keluarga tinggi dengan patuh minum obat sebanyak 12 orang (92,3\%). Dari hasil uji diperoleh nilai $p$-value adalah 0,005 ( $\mathrm{p}<0,05)$, maka ada hubungan signifikan antara dukungan keluarga terhadap kepatuhan minum obat pasien skizofrenia yang mengalami halusinasi.

Tabel 2

Hubungan perilaku dengan kepatuhan minum obat pasien skizofrenia yang mengalami halusinasi di RS Husada (n=24)

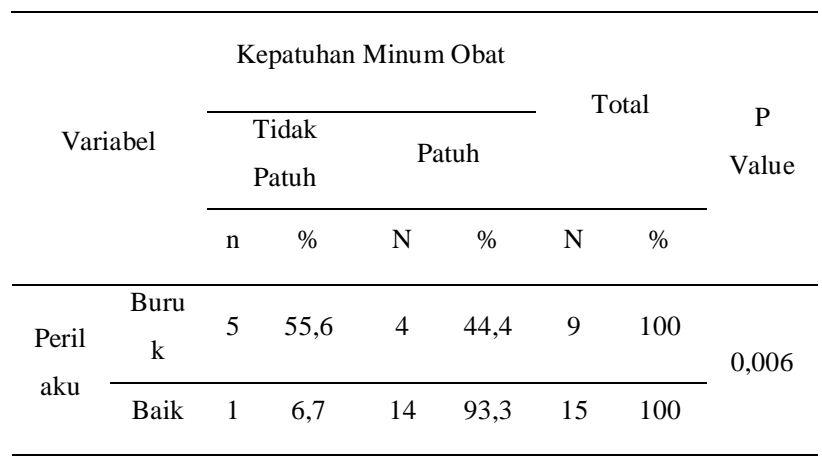


Perilaku buruk dengan tidak patuh minum obat sebanyak 5 orang $(55,6 \%)$, responden perilaku buruk dengan patuh minum obat sebanyak 4 orang $(44,4 \%)$, responden yang perilaku baik dengan tidak patuh minum obat sebanyak 1 orang $(6,7 \%)$, dan responden perilaku baik dengan patuh minum obat sebanyak 14 orang $(93,3 \%)$. Dari hasil uji diperoleh nilai p-value adalah 0,006 ( $\mathrm{p}<0,05)$, maka ada hubungan signifikan antara perilaku terhadap kepatuhan minum obat pasien skizofrenia yang mengalami halusinasi.

Tabel 3

Hubungan tingkat ekonomi dengan kepatuhan minum obat pasien skizofrenia yang mengalami halusinasi di RS Husada (n=24)

\begin{tabular}{|c|c|c|c|c|c|c|c|c|}
\hline \multirow{3}{*}{\multicolumn{2}{|c|}{ Variabel }} & \multicolumn{4}{|c|}{ Kepatuhan Minum Obat } & \multirow{2}{*}{\multicolumn{2}{|c|}{ Total }} & \multirow{3}{*}{$\begin{array}{c}\mathrm{P} \\
\text { Value }\end{array}$} \\
\hline & & \multicolumn{2}{|c|}{$\begin{array}{l}\text { Tidak } \\
\text { Patuh }\end{array}$} & \multicolumn{2}{|c|}{ Patuh } & & & \\
\hline & & $\mathrm{N}$ & $\%$ & $\mathrm{~N}$ & $\%$ & $\mathrm{~N}$ & $\%$ & \\
\hline \multirow{3}{*}{$\begin{array}{c}\text { Tingk } \\
\text { at } \\
\text { Ekono } \\
\text { mi }\end{array}$} & Kurang & 2 & 100 & 0 & 0 & 2 & 100 & \multirow{3}{*}{0,005} \\
\hline & Cukup & 3 & 37,5 & 5 & 62,5 & 8 & 100 & \\
\hline & Lebih & 1 & 7,1 & 13 & 92,9 & 14 & 100 & \\
\hline
\end{tabular}

Tingkat ekonomi kurang mencukupi dengan tidak patuh minum obat sebanyak 2 orang (100\%), responden tingkat ekonomi cukup dengan tidak patuh minum obat sebanyak 3 orang $(37,5 \%)$, responden tingkat ekonomi cukup dengan patuh minum obat sebanyak 5 orang $(62,5 \%)$, responden yang tingkat ekonomi sangat mencukupi dengan tidak patuh minum obat sebanyak 1 orang $(7,1 \%)$, dan responden tingkat ekonomi sangat mencukupi dengan patuh minum obat sebanyak 13 orang $(92,9 \%)$. Dari hasil uji diperoleh nilai $p$-value adalah $0,005(\mathrm{p}<0,05)$, maka ada hubungan signifikan antara tingkat ekonomi terhadap kepatuhan minum obat pasien skizofrenia yang mengalami halusinasi.

\section{Tabel 4}

Hubungan tingkat pendidikan dengan kepatuhan minum obat pasien skizofrenia yang mengalami halusinasi di RS Husada (n=24)

\begin{tabular}{|c|c|c|c|c|c|c|c|c|}
\hline \multirow{3}{*}{\multicolumn{2}{|c|}{ Variabel }} & \multicolumn{4}{|c|}{ Kepatuhan Minum Obat } & \multirow{2}{*}{\multicolumn{2}{|c|}{ Total }} & \multirow{3}{*}{$\begin{array}{c}\mathrm{P} \\
\text { Value }\end{array}$} \\
\hline & & \multicolumn{2}{|c|}{$\begin{array}{l}\text { Tidak } \\
\text { Patuh }\end{array}$} & \multicolumn{2}{|c|}{ Patuh } & & & \\
\hline & & $\mathrm{N}$ & $\%$ & $\mathrm{~N}$ & $\%$ & $\mathrm{~N}$ & $\%$ & \\
\hline \multirow{4}{*}{$\begin{array}{c}\text { Ting } \\
\text { kat } \\
\text { Pend } \\
\text { idika } \\
\text { n }\end{array}$} & SD & 1 & 100 & 0 & 0 & 1 & 100 & \multirow{4}{*}{0,031} \\
\hline & SMP & 2 & 100 & 0 & 0 & 2 & 100 & \\
\hline & SMA & 2 & 15,4 & 11 & 87,5 & 13 & 100 & \\
\hline & PT & 1 & 12,5 & 7 & 87,5 & 8 & 100 & \\
\hline
\end{tabular}

Responden yang pendidikan SD dengan tidak patuh minum obat sebanyak 1 orang $(100 \%)$, responden pendidikan SMP dengan tidak patuh minum obat sebanyak 2 orang (100\%), responden pendidikan SMA dengan tidak patuh minum obat sebanyak 2 orang $(15,4 \%)$, 
responden yang pendidikan SMA dengan patuh minum obat sebanyak 11 orang $(87,5 \%)$, responden pendidikan perguruan tinggi dengan tidak patuh minum obat sebanyak 1 orang $(12,5 \%)$, dan responden pendidikan perguruan tinggi dengan patuh minum obat sebanyak 7 orang $(87,5 \%)$. Dari hasil uji diperoleh nilai $p$-value adalah $0,031(\mathrm{p}<$ 0,05), maka ada hubungan signifikan antara tingkat pendidikan terhadap kepatuhan minum obat pasien skizofrenia yang mengalami halusinasi.

Tabel 5

Hubungan pengetahuan dengan kepatuhan minum obat pasien skizofrenia yang mengalami halusinasi di RS Husada (n=24)

\begin{tabular}{|c|c|c|c|c|c|c|c|c|}
\hline \multirow{3}{*}{\multicolumn{2}{|c|}{ Variabel }} & \multicolumn{4}{|c|}{ Kepatuhan Minum Obat } & \multirow{2}{*}{\multicolumn{2}{|c|}{ Total }} & \multirow{3}{*}{$\begin{array}{c}\mathrm{P} \\
\text { Value }\end{array}$} \\
\hline & & \multicolumn{2}{|c|}{$\begin{array}{l}\text { Tidak } \\
\text { Patuh }\end{array}$} & \multicolumn{2}{|c|}{ Patuh } & & & \\
\hline & & $\mathrm{N}$ & $\%$ & $\mathrm{~N}$ & $\%$ & $\mathrm{~N}$ & $\%$ & \\
\hline \multirow{3}{*}{$\begin{array}{l}\text { Peng } \\
\text { etahu } \\
\text { an }\end{array}$} & Rendah & 2 & 50 & 2 & 50 & 4 & 100 & \multirow{3}{*}{0,035} \\
\hline & Sedang & 3 & 42,9 & 4 & 57,1 & 7 & 100 & \\
\hline & Tinggi & 1 & 7,7 & 12 & 92,3 & 13 & 100 & \\
\hline
\end{tabular}

Responden pengetahuan rendah dengan tidak patuh minum obat sebanyak 2 orang (50\%), pengetahuan rendah dengan patuh minum obat sebanyak 2 orang $(50 \%)$, responden pengetahuan sedang dengan tidak patuh minum obat sebanyak 3 orang $(42,9 \%)$, responden pengetahuan sedang dengan patuh minum obat sebanyak 4 orang $(57,1 \%)$, responden yang pengetahuan tinggi dengan tidak patuh minum obat sebanyak 1 orang $(7,7 \%)$, dan responden pengetahuan tinggi dengan patuh minum obat sebanyak 12 orang (92,3\%). Dari hasil uji diperoleh nilai $p$-value adalah 0,035 ( $\mathrm{p}<0,05)$, maka ada hubungan signifikan antara pengetahuan terhadap kepatuhan minum obat pasien skizofrenia yang mengalami halusinasi.

\section{Tabel 6}

\section{Hubungan dukungan sosial dengan kepatuhan minum obat pasien skizofrenia yang mengalami halusinasi di RS Husada (n=24)}

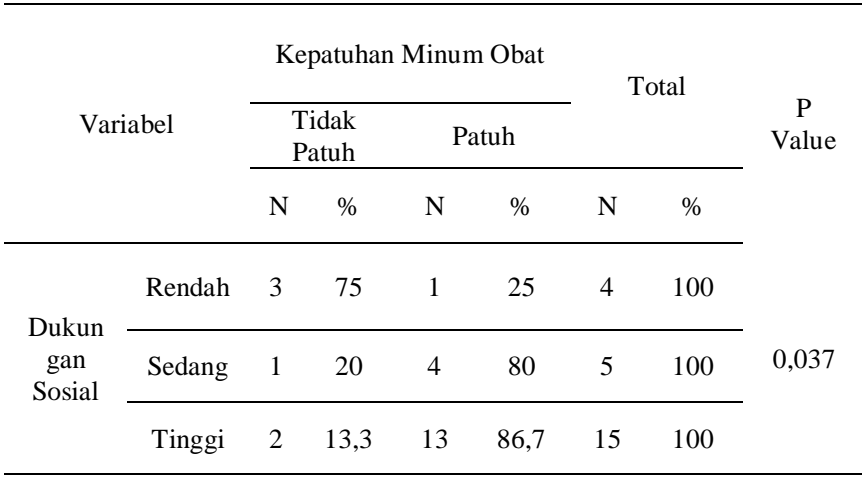

Responden dukungan sosial rendah dengan tidak patuh minum obat sebanyak 3 orang (75\%), responden dukungan sosial rendah dengan patuh minum obat sebanyak 1 orang (25\%), responden dukungan sosial sedang dengan tidak patuh minum obat sebanyak 1 orang (20\%), responden dukungan sosial sedang dengan patuh minum obat sebanyak 4 orang (80\%), 
responden yang dukungan sosial tinggi dengan tidak patuh minum obat sebanyak 2 orang $(13,3 \%)$, dan responden dukungan sosial tinggi dengan patuh minum obat sebanyak 13 orang $(86,7 \%)$. Dari hasil uji diperoleh nilai $p$-value adalah 0,037 ( $\mathrm{p}<0,05)$, maka ada hubungan signifikan antara dukungan sosial terhadap kepatuhan minum obat pasien skizofrenia yang mengalami halusinasi.

\section{PEMBAHASAN}

Hasil riset menunjukkan bahwa mayoritas responden yang mendapatkan dukungan keluarga tinggi sebanyak $54,2 \%$. Berdasarkan penelitian ditemukan bahwa angka kambuh pada pasien gangguan jiwa tanpa therapi keluarga sebesar 25-50\%, sedangkan angka kambuh pada pasien yang mendapat terapi keluarga adalah sebesar 5-10\% (Keliat, 2010).

Hasil penelitian menunjukkan bahwa mayoritas responden yang memiliki perilaku baik sebanyak $62,5 \%$. Menurut teori Kelman, perubahan sikap dan perilaku individu dimulai dengan tahap kepatuhan.
Penelitian ini menunjukkan bahwa mayoritas responden yang memiliki tingkat ekonomi sangat mencukupi sebanyak 58,4\%. Pada penelitian Shinta (2012), obat antipsikotik oral tipikal memiliki rata-rata hari rawat inap 116 hari, yang akan mempengaruhi biaya total perawatan yang akan semakin besar.

Hasil penelitian menunjukkan bahwa mayoritas responden yang memiliki tingkat pendidikan SMA sebanyak 54,2\%. Pasien dengan tingkat pendidikan rendah cenderung kurang memperhatikan kualitas hidup sehat, sehingga berpengaruh juga pada terapi (Amarita, 2004). Sebaliknya pasien dengan tingkat pendidikan tinggi cenderung untuk kritis terhadap kualitas kesehatan mereka.

Penelitian ini menunjukkan bahwa mayoritas responden yang memiliki pengetahuan tinggi sebanyak $54,1 \%$. Menurut hasil penelitian Joko S. dkk, (2013) responden dengan pengetahuan baik tentang skizofrenia ada 9 orang $(40,9 \%)$.

Hasil penelitian menunjukkan bahwa mayoritas responden yang mendapatkan 
dukungan sosial tinggi sebanyak 62,5\%.

Menurut Asima dan Winda (2009) dalam penelitiannya mengatakan bahwa $64,4 \%$ reponden mengalami ketidakpatuhan menjalani pengobatan karena dukungan sosial yang rendah.

Penelitian ini menunjukkan bahwa mayoritas responden yang patuh dalam minum obat sebanyak $75 \%$. Perilaku kepatuhan tergantung pada situasi klinis tertentu, sifat penyakit dan program pengobatan (Kaplan \& Sadock,2010). Kepatuhan terjadi bila aturan pakai obat yang diresepkan serta pemberiannya diikuti demgan benar. Jika terapi ini akan dilanjutkan setelah pasien pulang, penting agar pasien mengerti dan dapat meneruskan terapi itu dengan benar dan tanpa pengawasan.

Hasil bivariat pada penelitian menunjukkan bahwa pasien dengan dukungan keluarga tinggi dengan patuh minum obat sebanyak $92,3 \%$ dengan nilai $p$-value adalah 0,005 ( $\mathrm{p}<0,05)$ maka ada hubungan signifikan antara dukungan keluarga terhadap kepatuhan minum obat pasien skizofrenia. Hasil penelitian ini sejalan dengan penelitian yang dilakukan oleh Ruspawan (2009) di Poliklinik Rumah Sakit Jiwa Propinsi
Bali yang menyatakan bahwa ada hubungan yang signifikan antara peran keluarga pada kepatuhan minum obat dengan frekuensi kekambuhan pasien skizofrenia dengan hasil $\rho=0,000$.

Berdasarkan penelitian ditemukan bahwa angka kambuh pada pasien gangguan jiwa tanpa terapi keluarga sebesar 25-50\%, sedangkan angka kambuh pada pasien yang mendapat terapi keluarga adalah sebesar 5-10\% (Keliat, 2010).

Keluarga merupakan faktor yang sangat penting dalam proses kesembuhan pasien gangguan jiwa. Dengan keluarga yang bersikap terapeutik dan mendukung pasien, masa kesembuhan pasien dapat dipertahankan selama mungkin. Sebaliknya, jika keluraga kurang mendukung, angka kekambuhan menjadi cepat.

Pendidikan kesehatan keluarga diharapakan dapat menjadi sarana peberdayaan keluarga, baik ketika pasien masih dirawat dirumah sakit maupun setelah pulang kerumah. Pendidikan kesehatan individu keluarga adalah pendidikan kesehatan yang diberikan kepada keluarga pasien. Pendidikan 
kesehatan keluarga jenis ini merupakan bagian dari asuhan keperawatan pasien (anggota keluarga yang sedang dirawat). Materi pendidikan ini adalah cara mengatasi masalah keperawatan yang dialami oleh pasien yang dapat dilakukan oleh keluarga, baik dirumah sakit maupun dirumah.

Dukungan keluarga dalam penelitian ini adalah dengan mendorong pasien agar patuh meminum obatnya dan kontrol pada waktu yang ditentukan. Bila keluarga tidak mendukung dengan cara mengingatkan pasien untuk selalu meminum obatnya, maka penderita penyakit kronis sering gagal dalam pengobatannya.

Wulansih (dalam Sirait, 2009) kekambuhan yang dialami pasien disebabkan ketidakpatuhan pasien menjalani pengobatan. Untuk itu, perlu adanya dukungan dari keluarga, orangorang terdekat dan juga lingkungan sekitar. Melalui pengawasan secara intensif kepada pasien skizofrenia, maka kepatuhan dalam mengkonsumsi obat sehingga pasien merasa memiliki tambahan kekuatan dari keluarga dan orang terdekatnya.
PMO (Pengawasan Minum Obat) adalah orang yang ditunjuk untuk mengawasi dan mengingatkan pasien untuk minum obat untuk menjamin seseorang menyelesaikan pengobatan. Sebaiknya PMO adalah seseorang yang dekat dan dipercaya oleh pasien sehingga pasien akan menuruti ketika minum obat. Seperti, Ibu atau istri (bagi pasien yang sudah menikah) sangat membantu dalam pengawasan minum obat pada pasien skizofrenia.

Data diatas menunjukkan bahwa dukungan keluarga sangat mempengaruhi kepatuhan minum obat pada pasien skizofrenia, dengan cara mengingatkan pasien untuk minum obat tepat pada waktunya. Ibu atau istri (bagi pasien yang sudah menikah) sangat membantu dalam pengawasan minum obat pada pasien skizofrenia.

Hasil penelitian menunjukkan bahwa pasien dengan perilaku baik dengan patuh minum obat sebanyak 93,3\% dengan nilai $p$-value adalah 0,006 ( $\mathrm{p}<$ 0,05) maka ada hubungan signifikan antara perilaku terhadap kepatuhan minum obat pasien skizofrenia. Menurut teori Kelman, perubahan sikap dan perilaku individu dimulai dengan tahap 
kepatuhan. Mula-mula individu mematuhi anjuran atau instruksi tanpa kerelaan untuk melakukan tindakan tersebut dan seringkali karena ingin menghindari hukuman atau sanksi jika tidak patuh, atau untuk memperoleh imbalan yang dijanjikan jika mematuhi anjuran tersebut, tahap ini disebut tahap kesediaan.

Biasanya perubahan yang terjadi dalam tahap ini bersifat sementara, artinya bahwa tindakan itu dilakukan selama masih ada pengawasan petugas. Tetapi begitu pengawasan itu mengendur atau hilang, perilaku itupun ditinggalkan (Niven, 2002).

Selain itu, perilaku juga dipengaruhi oleh beberapa faktor, salah satunya usia dan jenis kelamin. Menurut Pariwisata (2006) hasil statistik pada usia 15-30 tahun banyak terjadi pada pasien skizofrenia, namun pada imunologi dikenal juga penyakit skizofrenia yang dialami oleh anak-anak sekitar usia 8 tahun dan skizofrenia pada usia lanjut lebih dari 45 tahun.

Menurut hasil penelitian Dyah (2012) jumlah pasien laki-laki selama periode penelitian dua kali lipat jumlah pasien perempuan. Hal ini dapat disebabkan diantaranya karena adanya efek neuroprotektif dari hormon pada wanita dan kecenderungan yang lebih besar mendapatkan trauma kepala pada pria (Seeman, 2004; Lalloo, 2003). Beberapa penelitian telah menyatakan bahwa pria akan lebih mungkin daripada wanita untuk mengalami gangguan gejala negatif dan wanita lebih mungkin untuk memiliki fungsi sosial yang lebih baik dari pria (Kaplan, 1997). Pada umumnya hasil akhir untuk pasien schizophrenia wanita lebih baik daripada hasil akhir pasien pria. Ini kemungkinan salah satu penyebab pasien yang dirawat lebih banyak yang pria dibandingkan wanita. Hasil penelitian ini senada dengan penelitian yang dilakukan oleh Kurihara et al, 2006 yang menemukan bahwa dari 39 pasien schizophrenia, 25 diantaranya adalah pria dan 14 lainnya wanita.

Dari data diatas menunjukkan bahwa salah satu faktor kepatuhan minum obat pada pasien skizofrenia adalah perilaku yang baik. Hasil penelitian menunjukkan bahwa pasien dengan tingkat ekonomi sangat mencukupi dengan patuh minum obat sebanyak $92,9 \%$ dengan nilai $p$ value adalah $0,005(\mathrm{p}<0,05)$ maka ada hubungan signifikan antara tingkat ekonomi terhadap kepatuhan minum 
obat pasien skizofrenia. Pada penelitian Shinta (2012), obat antipsikotik oral tipikal memiliki rata-rata hari rawat inap 116 hari, yang akan mempengaruhi biaya total perawatan yang akan semakin besar. Menurut Syumanda (2009), melalui gaya hidup yang tidak baik dapat menimbulkan berbagai penyakit.

Orang dengan skizofrenia perlu mendapatkan penanganan menyeluruh dan efektif. Hal itu dapat memperbaiki kualitas hidup penderita dan mengembalikannya pada kehidupan yang normal. Sementara itu, penanganan yang tidak efektif bisa mengakibatkan gangguan berlangsung bertahun-tahun sehingga dapat menghabiskan banyak biaya dan akibatnya bisa terjadi penurunan status ekonomi keluarga (Pikiran Rakyat, 2011).

Lama rawat inap pasien akan berpengaruh pada biaya yang dikeluarkan pasien tersebut untuk pengobatannya. Menurut WHO, lama rawat inap pasien skizofrenia dibagi menjadi 3 kategori, yaitu kategori akut dengan rawat inap $<35$ hari, kategori sub akut dengan waktu perawatan 35103 hari dan kronik apabila lama rawat lebih dari 103 hari. Pada penelitian ini, obat antipsikotik oral tipikal memiliki rata-rata hari rawat inap 116 hari, yang akan mempengaruhi biaya total perawatan yang akan semakin besar. Hal ini memungkinkan kelompok pengobatan ini menghasilkan biaya pengobatan yang tertinggi. Pada pasien kelompok terapi oral atipikal, rata-rata hari rawat inap adalah 67 hari, jumlah hari rawat inap setengah dari rerata oral tipikal, sehingga biaya keseluruhan pengobatan pun akan menjadi lebih kecil dibandingkan oral tipikal. Kelompok terakhir dengan terapi injeksi tipikal memiliki rata-rata rawat inap terpendek, yaitu 30 hari. Dengan begitu, biaya yang dikeluarkan selama perawatan pun cenderung paling rendah. Sehingga lama rawat inap menjadi suatu poin penting dalam perhitungan efektivitas biaya pengobatan pasien skizofrenia ini.

Waktu kekambuhan didefinisikan sebagai waktu munculnya kembali gejala seperti di awal penyakitnya. Gejala pada pasien skizofenia yang sudah dinyatakan stabil akan meningkat, sehingga pasien membutuhkan pengobatan dari fase akut lagi. Kaplan (2006) menyatakan, pasien skizofrenia dinyatakan kambuh kembali apabila peningkatan gejala muncul $<12$ bulan, sejak riwayat pengobatan akut 
terakhirnya. Tingkat kekambuhan ini nantinya akan berhubungan dengan efektivitas terapi pasien, yang akan berujung pada jumlah pembiayaan pasien tersebut.

Dari data diatas menunjukkan bahwa tingkat ekonomi sangat mempengaruhi kepatuhan dalam pengobatan, karena kebutuhan untuk membeli obat-obatan pasien skizofrenia tergolong mahal. Serta disarankan untuk keluarga pasien menggunakan jaminan kesehatan seperti BPJS untuk mengurangi biaya pengobatan yang tinggi.

Hasil penelitian menunjukkan bahwa pasien dengan pendidikan SMA dengan patuh minum obat sebanyak $87,5 \%$ dengan nilai $p$-value adalah $0,031(\mathrm{p}<$ 0,05) maka ada hubungan signifikan antara tingkat pendidikan terhadap kepatuhan minum obat pasien skizofrenia. Pasien dengan tingkat pendidikan rendah cenderung kurang memperhatikan kualitas hidup sehat, sehingga berpengaruh juga pada terapi (Amarita, 2004). Sebaliknya pasien dengan tingkat pendidikan tinggi cenderung untuk kritis terhadap kualitas kesehatan mereka.
Berdasarkan hasil penelitian dari Dyah (2012) berpendapat terkait dengan tingkat pendidikan bahwa pasien dengan tingkat pendidikan rendah cenderung kurang memperhatikan kualitas hidup sehat, sehingga berpengaruh juga pada terapi pengobatan. sebaliknya pasien dengan tingkat pendidikan tinggi cenderung untuk kritis terhadap kesehatan mereka. Sesuai dengan penelitian yang dilakukan cenderung pasien berpendidikan tinggi sehingga memperhatikan kualitas kesehatan dan terapi jiwa mereka.

Ada kecenderungan semakin rendah pendidikan seseorang maka akan tidak patuh dalam meminum obat. Tingkat pendidikan berhubungan dengan kemampuan menerima informasi kesehatan dari media massa dan petugas kesehatan. Banyak kasus kesakitan dan kematian masyarakat diakibatkan rendahnya tingkat pendidikan penduduk.

Jenjang pendidikan memegang peranan penting dalam kesehatan masyarakat (Sander, 2005). Jadi pendidikan berpengaruh pada kepatuhan minum obat adalah benar adanya.

Data diatas pasien rata-rata memiliki pendidikan terakhir SMA dan 
menunjukkan bahwa salah satu faktor kepatuhan minum obat pasien skizofrenia adalah pendidikan yang tinggi.

Hasil penelitian menunjukkan bahwa pasien dengan pengetahuan tinggi dengan patuh minum obat sebanyak 92,3\% dengan nilai $p$-value adalah 0,035 $(\mathrm{p}<0,05)$ maka ada hubungan signifikan antara pengetahuan terhadap kepatuhan minum obat pasien skizofrenia. Menurut hasil penelitian Joko S. dkk, (2013) responden dengan pengetahuan baik tentang skizofrenia ada 9 orang $(40,9 \%)$.

Ada kecenderungan semakin rendah pengetahuan seseorang maka akan tidak patuh dalam meminum obat. Pengetahuan adalah merupakan hasil dari tahu, dan ini terjadi setelah orang melakukan penginderaan terhadap suatu objek tertentu. Penginderaan ini terjadi melalui panca indera manusia, yaitu indera penglihatan, pendengaran, penciuman, rasa dan raba. Pengetahuan atau kognitif merupakan domain yang sangat penting untuk terbentuknya perilaku seseorang (Notoatmodjo. 2004). Hasil pnelitian diatas menunjukkan pengetahuan yang tinggi terhadap jenis, manfaat dari obat-obatan dapat mempengaruhi kepatuhan minum obat pada pasien skizofrenia.

Hasil penelitian menunjukkan bahwa pasien dengan dukungan sosial tinggi dengan patuh minum obat sebanyak $86,7 \%$ dengan nilai $p$-value adalah 0,037 $(\mathrm{p}<0,05)$ maka ada hubungan signifikan antara dukungan sosial terhadap kepatuhan minum obat pasien skizofrenia. Berdasarkan hasil penelitian Asima dan Winda (2009) menunjukkan faktor lingkungan merupakan penyebab ketidakpatuhan dengan persentase 64.4\%. Hal ini sejalan dengan pendapat Simanjuntak (2008) menyebutkan bahwa dukungan dan bantuan merupakan variabel penting dalam kepatuhan terhadap pengobatan. Pasien yang tinggal sendirian secara umum mempunyai angka kepatuhan yang rendah dibandingkan mereka yang tinggal dalam lingkungan yang mendukung. Sebagai kemungkinan lain, sikap negatif dalam lingkungan sosial pasien terhadap pengobatan psikiatri atau terhadap pasien sendiri dapat mempengaruhi kepatuhan. Interaksi sosial yang penuh dengan stress dapat mengurangi kepatuhan yang biasanya terjadi bila pasien tinggal dengan orang lain. Sebagai contohnya adalah situasi 
emosional yang tinggi dan keluarga atau pihak lain yang tidak mau memperhatikan sikap positif pasien terhadap pengobatan.

Menurut Butler (2002) adanya dukungan orang terdekat atau keluarga membuat pasien merasa lebih berarti dan memotivasinya untuk memiliki kepercayaan diri agar mampu beradaptasi dengan kondisinya. Selain itu, tidak adanya dukungan sosial dan kehidupan yang tidak mapan menciptakan lingkungan yang tidak mendukung dalam program tercapainya kepatuhan pasien dan kompleksitas regimen pengobatan merupakan faktor yang mempunyai efek negatif terhadap kepatuhan (Dewi,2009).

Dari data diatas menunjukkan bahwa pasien dengan dukungan sosial yang tinggi memiliki peran yang berati terhadap kepatuhan minum obat pada pasien skizofrenia. Selain itu mengikuti organisasi yang menaungi pasien skizofrenia, seperti Komunitas Peduli Skizofrenia Indonesia (KPSI).

\section{DAFTAR PUSTAKA}

Arif, Iman Setiadi. (2006). Memahami Dinamika Keluarga Pasien
Skizofrenia. Bandung : Rafika Aditama.

Arikunto, (2006). Metodelogi Penelitian. Jakarta : Rhineka Cipta.

Burn, N. \& Grove, S.K. (2001). The practice of Nursing Research : Conduct, Critique \& Utilization. $\left(2^{\text {th }} e d\right)$. Philadelpia : WB. Squnders Company.

Christiawati, Agustini. (2012). Hubungan Cara Bayar, Jarak Tempat Tinggal Dan Dukungan Keluarga Dengan Kepatuhan Berobat Rawat Jalan Pasien Skizofrenia Di RSJD Surakarta. Naskah Publikasi.

Dahlan, S. (2006). Besar Sampel dalam Penelitian Kedokteran dan Kesehatan. Jakarta : ARKANS.

Dahlan, S. (2008). Langkah-Langkah Membuat Proposal Penelitian Bidang Kedokteran dan Kesehatan. Jakarta : Sagung Seto.

Dahlan, S. ( 2011). Statistik untuk Kedokteran dan Kesehatan. Jakarta : Salemba Medika.

Eunike, Agustina. (2013). Statistik Industri $1 . \quad$ (online). http://aeunike.lecture.ub.ac.id/files/2 013/11/6-Metode-Sampling.pdf. diakses pada 4 Februari 2015.

Fadli, Mulya Suryadi. (2013). Pengetahuan dan Ekspresi Emosi Keluarga serta Frekuensi Kekambuhan Penderita Skizofrenia. Jurnal Kesehatan Masyarakat Nasional Vol. 7, No.10, Mei 2013.

Fakhrudin. (2013). Hubungan Dukungan Sosial Dengan Kepatuhan Minum Obat Penderita Skizofrenia Di 
Kabupaten Aceh Barat Daya. Online:

http://etd.ugm.ac.id/index.php?mod $=$ penelitian_detail\&sub=PenelitianD etailact=view\&typ=html\&buku_id= 58938\&obyek_id=4 di akses tanggal 5 Maret 2014.

Kaplan, H. Sadock, B. Grebb, J. (2010). Sinopsis Psikiatri, jilid 1. Tanggerang : Binarupa Aksara Publisher.

Kaunang, Esrom \& Vanri. (2015). Hubungan Kepatuhan Minum Obat Dengan Prevalensi Kekambuhan Pada Pasien Skizofrenia Yang Berobat Jalan Di Ruang Poliklinik Jiwa Rumah Sakit Prof Dr. V. L. Ratumbuysang. Ejournal Keperawatan (e-Kp), Volume 2, No. 2, Mei 2015.

King, Bruce M., Edward W. Minium. (2003). Statistical Reasoning in Psychology and Education, Fourth Edition. USA : John Wiley \& Sons.

Lesmanawati, Dyah Ayu. (2012). Analisis Efektivitas Biaya Penggunaan Terapi Antipsikotik Pada Pasien Skizofrenia Di Instalasi Rawat Inap Rumah Sakit Jiwa Grhasia Yogaykarta. Online. http://digilib.fk.umy.ac.id/gdl.php? mod=browse\&op=read\&id=yoptum yfkpp-gdl-megairiani-860 diunduh pada 15 Mei 2015.

Muslim. (2010). Populasi dan Sampling. (online).

http://muslimpinang.files.wordpress. com/2010/10/sampling1.pdf. diakses 10 Februari 2014.
Notoatmojo, S. (2010). Metedologi Penelitian Kesehatan. Jakarta : Rineka Cipta.

Nursalam. (2001). Konsep dan Penerapan Metedologi Penelitian Ilmu Keperawatan. Jakarta : Salemba Medika.

Pariwisata. (2006). Skizofrenia. (http://www.faktor-kekambuhanskizofrenia.com Diakses 6 Februari 2015).

Pratiwi, Inneke. (2011). Faktor-Faktor Yang Berhubungan Dengan Kepatuhan Minum Obat Pada Pasien Skizofrenia Di Poliklinik RSJ Prof. Dr HB Saanin Padang Tahun 2011. Skripsi.

Puspitasari. (2009). Peran Dukungan Keluarga Pada Penangan Penderita Skizofrenia. (Diakses 21 Februari 2015).

Purwanto, Anang. (2010). Faktor-Faktor Yang Berhubungan Dengan Kekambuhan Pasien Skizofrenia Di Rumah Sakit Jiwa Daerah Surakarta. Skripsi.

Kementerian Kesehatan. (2013). Riset Kesehatan Dasar 2013.

Setiadi. (2007). Konsep Dan Penulisan Riset Keperawatan. Edisi Pertama. Yogyakarta : Graha Ilmu.

Sirait, A. Dan Mustika, W. (2009). Faktor-Faktor Penyebab Ketidakpatuhan Pasien Skizofrenia Menjalani Pengobatan Dirumah Sakit Jiwa Daerah Propinsi Sumatera Utara Medan Tahun 2009. Skripsi.

Sujatno, M. R. (2010). Metedologi Penelitian Biomedis. (online). http://repository.maranatha.edu/252 
2/3/Metlit\%20BAB\%20II.pdf diakses pada 10 Mei 2015.

Sulistyono, Kusuma Ika, \& Weny Hastuti. (2012). Faktor-Faktor Yang Mempengaruhi Ketidakpatuhan Minum Obat Pada Pasien Skizofrenia Di RSJD Surakarta. Skripsi.

WHO. (2009). Improving Health System and Service for Mental Health :
WHO Library Cataloguing - in Publication Data.

WHO (2010). Mental Health and Development : targeting people with mental health conditions as a vulnerable group : WHO Library Catologuing-in-publication.

Yusuf, A. M. (2002). Pengantar Ilmu Pendidikan. Jakarta : Ghalia Indonesia. 